\title{
Day roosts and roost-site selection of Ikonnikov's whiskered bat, Myotis ikonnikovi, in Nikko, Japan
}

\author{
Sachiko Yasui ${ }^{1, *}$, Takashi Kamijo ${ }^{2}$, Akiko Mikasa ${ }^{3}$, Mayumi Shigeta ${ }^{4}$ and Ikutaro Tsuyama ${ }^{2}$ \\ ${ }^{1}$ Asian Bat Research Institute, 213-3 Hirookacho, Nara, Nara 630-1101, Japan \\ ${ }^{2}$ Graduate School of Life and Environmental Science, University of Tsukuba, Tsukuba, Ibaraki 305-8572, Japan \\ ${ }^{3}$ Bat Study and Conservation Group of Japan, 8-20-3 Hisagi, Zushi, Kanagawa 249-0001, Japan \\ ${ }^{4}$ Wildlife Management Company, 1-21-14-B Akanedai, Aoba-ku, Yokohama, Kanagawa 227-0066, Japan
}

\begin{abstract}
Roost-site preferences of the tree-roosting bat (Myotis ikonnikovi) were examined using radio telemetry. Field investigations were conducted in Nikko, Tochigi, Japan, during the summers of 2001 and 2002. We radio-tracked nine bats, and 16 roost trees were found. Bats actively selected snags, more decayed stages of snags and larger stem diameters, compared to available trees in roost plots and trees in random plots. Bats changed roosts every 1 or 2 days. Low roost fidelity indicated that $M$. ikonnikovi needed many roosting trees. Of these roost trees, six were determined roost-sites: Four roosts were located under bark, one was in a small cavity of a broken stem, and one was in a narrow space between a climbing vine (liana) and a trunk. To improve conservation of M. ikonnikovi, a substantial number of snags and large trees must be preserved in the bat's habitat.
\end{abstract}

Key words: bark, Myotis, roost selection, snag, tree roost.

Many species of Japanese Chiroptera are listed in Threatened Wildlife of Japan - Red Data Book, edited by the Japanese Ministry of the Environment (Ministry of the Environment of Japan 2002). Most threatened microchiroptera are tree-roosting bats living in forests. Declines in the distribution and abundance of tree roosting bats are evident. This decline is mainly due to the fragmentation and destruction of bat habitat by the replacement of natural forests with plantation forests, and decreases in available roosting sites due to the removal of old trees (Maeda and Matsumura 1997).

Myotis ikonnikovi is distributed in Honshu and Hokkaido, Japan, east of Siberia and Sakhalin (Abe et al. 1994), and each subspecies is classified as 'endangered' or 'vulnerable' (Ministry of the Environment of Japan 2002). In our previous study, we analyzed the relationship between the distribution of M. ikonnikovi and actual vegetation, suggesting that old growth forest is an important habitat for this bat species (Yasui et al. 2000). According to Maeda and Matsumura (1997), M. ikonnikovi is categorized as a tree-cavity roosting bat, and little is known about the bat's day roosts, except for a few reports: trees (Yasui et al. 2002), a cave (Yokoyama 1996, M. fujiensis in the original text) and man-made structures (Mizuno 1970, M. hosonoi in the original text; Yamamoto et al. 1998).

Bats use roost sites for such activities as copulation, hibernation, and maternal care, and spend over half of their lifetime inside the roost (Kunz 1982; Altringham 1996). Roost-site availability is one of the limiting factors affecting the distribution and abundance of temperate bats (Humphrey 1975; Kunz 1982). Although information on roost sites is important for conservation purposes, data are insufficient because of the difficulties of investigating tree roosts. Recently, the use of small radio transmitter has made it possible to investigate roost sites of tree roosting bats, and many studies of roost-site selection have been conducted in New Zealand, Australia and North America (Kunz and Lumsden 2003). Various species of temperate microchiroptera have been reported selecting old growth trees (e.g., Brigham et al. 1997; Sedgeley and O'Donnell 1999) and snags (standing dead trees: e.g., Vonhof and Barclay 1996; Brigham et al. 1997; Foster and Kurta 1999; Sedgeley and O’Donnell

*To whom correspondence should be addressed.4-10-1-902-204 Namiki, Tsukuba, Ibaraki 305-0044, Japan. E-mail: QZV11613@nifty.com 
1999) as summer roosts. In Japan, on the other hand, only two case studies of roost sites using small radio transmitter have been conducted: Eptesicus nilssonii and Plecotus auritus in Hokkaido (Maeda et al. 1993), and M. ikonnikovi in Tochigi (Yasui et al. 2002).

The purpose of this study was to describe the characteristics of M. ikonnikovi day roosts and to assess roostsite preferences of this species. We evaluated habitat selection by comparing roost sites with randomly sampled available trees and with trees close to roost sites. Identification of bats and plants was based on Abe et al. (1994) and Ohwi (1992), respectively.

\section{Materials and methods}

\section{Study area}

The study was conducted in the southwestern area of Mt. Nantai in Nikko, Tochigi Prefecture, central Japan $\left(36^{\circ} 45^{\prime}, 139^{\circ} 27^{\prime}, 1,250-1,700 \mathrm{~m}\right.$ a.s.l.; Fig. 1). The study area was located on a gentle slope of Mt. Nantai, north of Lake Chuzenji. The vegetation was dominated by old-growth temperate mixed forests [conifers (Abies homolepis), and deciduous broad-leaved trees (Quercus mongolica var. grosseserrata, Ulmus davidiana var. japonica)], secondary forests of $Q . m$. var. grosseserrata, and plantations of Larix leptolepis. The annual precipitation and average temperature were $1,975 \mathrm{~mm}$ and $5.5^{\circ} \mathrm{C}$, respectively, at Chugushi (1,432 $\mathrm{m}$ a.s.l.) south of the study area (Japan Meteorological Agency 2002).

\section{Capture of bats and location of roosts}

Roosts were found in early August 2001 and during late July to early August 2002, by following radio-tagged bats. Bats were captured in mist nets set over slowmoving water and across roads in a forest. For each individual, species and sex were identified. The degree of ossification of the metacarpal-phalanx joints was examined to identify the bat as a yearling or not. Body weight and forearm length were also measured. We determined pregnancy by palpation and distinguished lactation from post-lactation by the condition of teats. Small radio transmitters (0.47-0.50 g: Model LB-2, Holohil Systems Ltd., Carp, Ont., Canada) were attached between the scapulae of each bat using surgical adhesive Skin-Bond (Smith and Nephew United, Inc., Largo, Florida). Transmitter weight represented $7.3-7.8 \%$ of female body weight, and $6.8-7.6 \%$ of male body weight. Radiotagged bats were tracked during the day using receivers (FT-290 mk II, Yaesu Radio Co. Ltd., Japan), and either

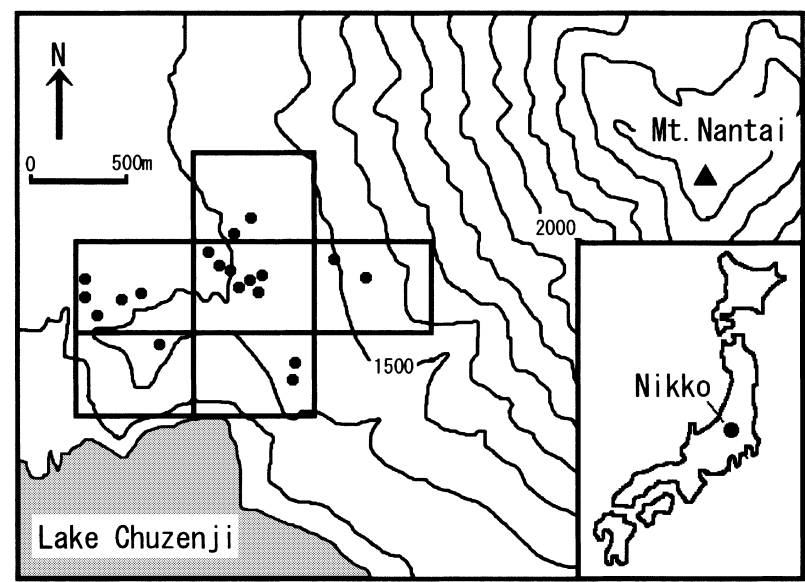

Fig. 1. The study area and distribution of roosts in the six $0.45 \times$ $0.55 \mathrm{~km}$ grid squares. Available trees in random plots within these grid squares were examined using the point-centered quarter (PCQ) method (see text).

three- or four-element Yagi antennae. After identifying the roost trees by radio-tracking, we observed each roost tree, watching and/or recording bat emergence by video with infrared light at dusk. This provided data about the height and aspect of the roost site, and the number of individuals emerging from the roost.

\section{Roost characteristics}

For each identified roost tree, the species name, diameter at breast height (DBH), tree height, entrance height and bark remaining (\%) were recorded. The percentage of bark remaining was visually estimated to the nearest $5 \%$ in the field. Height of trees was measured either with a Blume-Leiss altimeter or a measuring pole. We classified each roost tree into one of nine decay stages based on characteristics of trees: percent bark remaining, condition of the crown, and presence of twigs and branches:

Stage 1 Live, healthy; no decay; no obvious defects

Stage 2 Live, usually unhealthy; obvious defects such as broken crown, cracks, or hollows

Stage 3 Dead; recently dead; dead needles still present in evergreen conifer, many twigs present

Stage 4 Dead; no needles in evergreen conifer, few twigs, more than half of branches lost, bark loose, crown often broken

Stage 5 Dead; most branches and bark lost, crown broken

Stage 6 Dead; no branches or bark, broken off along mid-trunk

Stage 7 Dead; stubs $>3 \mathrm{~m}$ in height

Stage 8 Dead; stubs $<3 \mathrm{~m}$ in height

Stage 9 Debris; downed stubs or stumps 
These stages are modified from Vonhof and Barclay (1996) and Hunter (1990).

\section{Sampling of trees}

To assess roost-tree preference, we measured available trees in random plots and available trees in roost plots. We used the minimum dimensions observed for $\mathrm{DBH}$ and tree height of roost trees as a guideline designating the lower limit acceptable for an available tree. An available tree was defined as follows based on our results of roost trees: $\mathrm{DBH} \geq 20 \mathrm{~cm}, \geq 5 \mathrm{~m}$ tall and decay stage $\leq 7$. The smallest $\mathrm{DBH}$, the lowest tree height, and the greatest decay ranking of actual identified roost trees was $23.6 \mathrm{~cm}, 7 \mathrm{~m}$, and stage 7 , respectively.

(1) Available trees in random plots. Trees were sampled throughout the roosting area using the pointcentered quarter (PCQ) method (Cottam and Curtis 1956). We used quartered grids (approximately $0.45 \times$ $0.55 \mathrm{~km}$ ) of the grid map issued by Ministry of the Environment of Japan to determine the starting point of the PCQ. In our study, six of the quartered grids contained roosting trees (Fig. 1). The starting point of each transect line was located on the midpoint of the west side of each grid square using a topographical map and a global positioning system (GPS). The transect line followed an easterly direction, and 20 points were selected at $20-\mathrm{m}$ intervals along the line. At each point, we marked four quadrants and selected the nearest available tree in each quadrant. Tree species, $\mathrm{DBH}$, distance from the point to each tree and decay stage were recorded for each selected tree. The distance was used to calculate the density of available trees such that $y=x^{-2}$, where $y$ represents density and $x$ represents the average distance from each point to an available tree.

(2) Available trees in roost plots. We marked four quadrants around each roost tree and located the nearest available tree in each quadrant. Tree species, DBH, distance from a roost tree to an available tree, and decay stage, were recorded.

\section{Data analysis}

Statistical analyses were conducted for comparisons between roost trees and available trees in random plots, and for comparisons between roost trees and available trees in roost plots. Fisher's exact probability test was used to test differences in the frequency of snags. A nonparametric Mann-Whitney $U$-test was used to test differences in DBH and decay stage. Statistical differences between tree species could not be determined, since the sample sizes were small in terms of each species. Windows Stat View (SAS Institute Inc.) was used for statistical analyses.

\section{Results}

\section{Radio-tracked bats}

A total of nine bats were radio-tracked; four were followed in 2001 and five in 2002. The sex and reproductive status of these bats were as follows: five males, one lactating female, two post-lactating females and one non-reproductive female. All tagged bats were not yearlings. Two of the five males could not be re-located. We located seven bats for 1-6 days, and found that each bat switched between $1-5$ roosts, every 1 or 2 days. The distance from capture sites to roost sites was $0.4 \mathrm{~km}, 0.8 \mathrm{~km}$ and $1.2 \mathrm{~km}$ for males, and $0.5 \mathrm{~km}, 0.8 \mathrm{~km}, 1.1 \mathrm{~km}$ and $1.1 \mathrm{~km}$ for females. The mean distance among consecutive roosts was $( \pm S D) 115 \pm 120 \mathrm{~m}$ (range 0-290 m, $n=$ 6 ) for males, and $( \pm S D) 163 \pm 163 \mathrm{~m}$ (range $0-560 \mathrm{~m}, n=$ 9) for females.

\section{Roost tree and roost site}

We found 16 roost trees, consisting of eight tree species: Ulmus davidiana var. japonica, Abies homolepis, Larix leptolepis, Quercus mongolica var. grosseserrata, Betula schmidtii, Carpinus cordata, Betula platyphylla var. japonica and Betula ermanii (see Appendix 1).

Nine out of 16 roost trees were snags. The average $\mathrm{DBH}$ and height of roost trees were $( \pm S D) 56.7 \pm 26.7$ cm (range 23.8-110.5 cm, $n=16$ ), and $( \pm S D) 15.8 \pm 4.9$ $\mathrm{m}$ (range $7.1-20.5 \mathrm{~m}, n=16$ ), respectively. The average remaining bark (\%) of roost trees was $( \pm S D) 87.9 \pm 23.6$ (range $30-100 \%, n=7$ ) for live trees and $( \pm S D) 41.7 \pm$ 23.6 (range $10-90 \%, n=9$ ) for snags. The average height of the roost entrance was $( \pm S D) 10.0 \pm 3.7 \mathrm{~m}$ (range 5.9-19.0 m, $n=10$ ).

Six roost sites were identified: four under bark (Fig. 2 ), one small cavity in a broken stem, and one roost in the space between a climbing liana and a trunk. On five out of six roost sites, we observed the antenna of the radio transmitter attached to the bat during the day and/or at dusk, when bats emerged from the roost.

Of five roosts in which the number of individuals was examined, four were used by a single bat. The remaining roost under the bark of a snag was used by five individuals, including a radio-tracked lactating female (Fig. 2). 

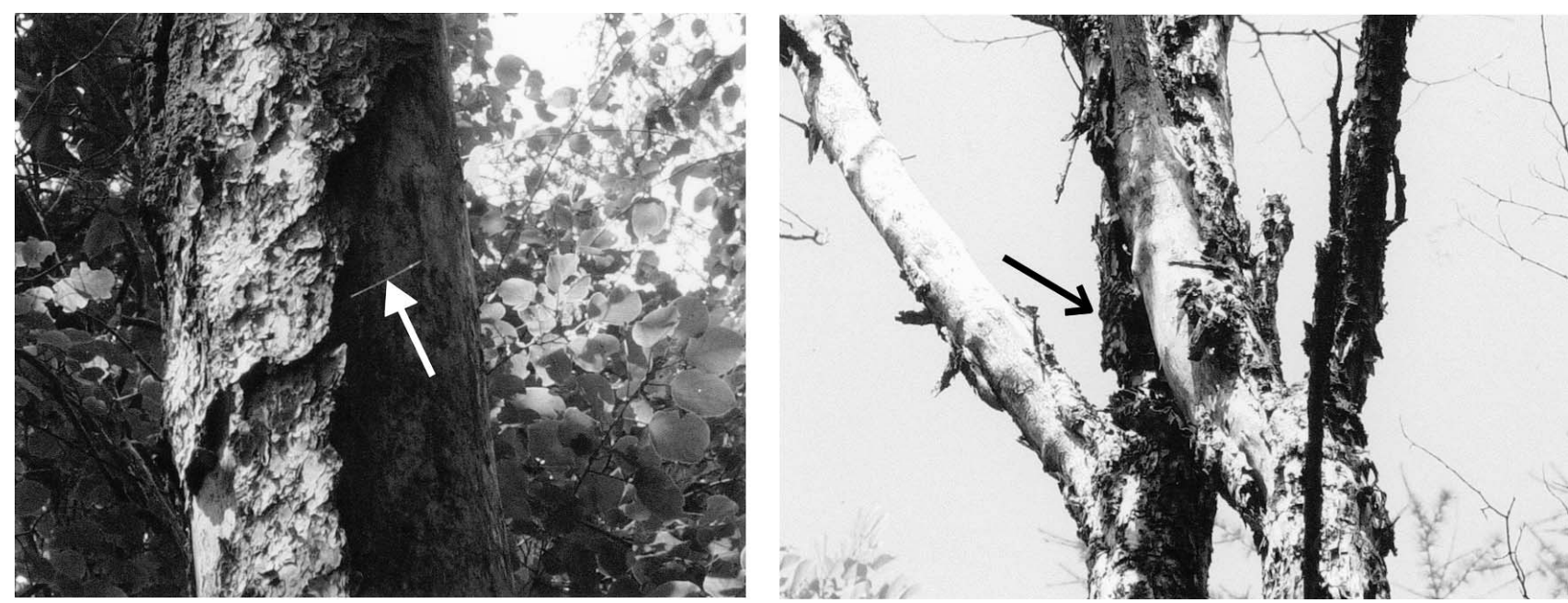

Fig. 2. Roost sites of Myotis ikonnikovi. Roosts were determined in crevices beneath exfoliating bark of snags of Larix leptolepis (left) and Ulmus davidiana var. japonica (right). The antenna of a radio transmitter attached to a bat can be seen in the left photograph (white arrow). The black arrow in the right photograph indicates the roost, located beneath exfoliating bark. The number of confirmed bats was one (left) and five (right), respectively.

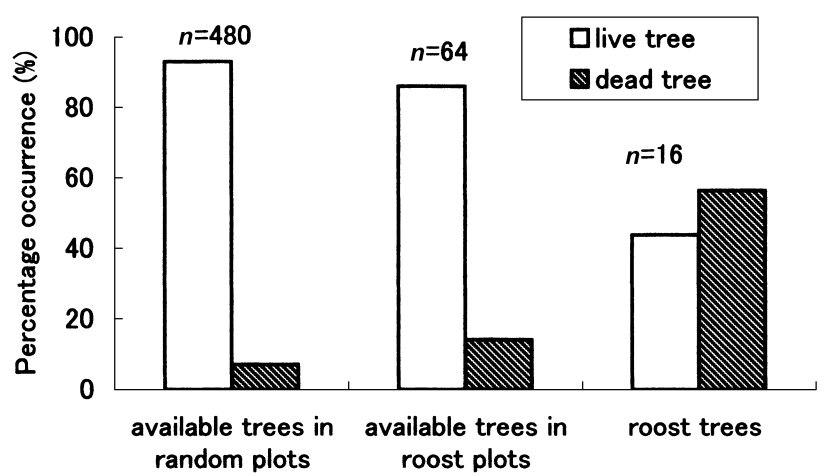

Fig. 3. Percentages for the use of dead and live trees as bat roosts compared with available trees in random plots and trees in roost plots.

\section{Roost-site selection}

(1) Snag frequency (Fig. 3). The density of available trees (DBH $\geq 20 \mathrm{~cm}$ ) was $3.07 / \mathrm{km}^{2}$ and snag density was $0.22 / \mathrm{km}^{2}$ in the roosting area.

The frequency of snags among roost trees was significantly higher than the frequency of snags among available trees in random plots (Fisher's exact probability test, $P<0.0001$ ), and significantly higher than that of snags among available trees in roost plots (Fisher's exact probability test, $P=0.001)$. The percentage frequencies of snags among roost trees, in available trees in random plots, and in roost plots were $56.3 \%, 7.1 \%$ and $14.1 \%$, respectively. The frequency of snags among available trees in roost plots was higher than that of snags among available trees in random plots, but not significantly so (Fisher's exact probability test, $P>0.05$ ).
(2) Decay stage (Fig. 4). The decay stages of roost trees were higher than those of available trees in the roost plot (Mann-Whitney $U$-test, $U=257, P=0.0022$ ), and higher than those of available trees in random plots (Mann-Whitney $U$-test, $U=1722, P=0.0002$ ). However there was no significant difference between available trees in roost plots and in random plots (MannWhitney $U$-test, $U=14596, P>0.05)$. The frequency of healthy live trees (decay stage 1) was $80 \%$ for available trees in both roost plots and random plots, whereas the frequency of healthy live trees among roost trees was approximately $30 \%$. Following stage 1 , the next most frequent roost tree was stage 4 (snags).

(3) $\mathrm{DBH}$ (Fig. 5). Roost trees had significantly larger stem diameters than available trees in roost plots (MannWhitney $U$-test, $U=349, P=0.0499$ ) and in random plots (Mann-Whitney $U$-test, $U=2369, P=0.0091$ ). There was no significant difference between available trees in roost plots and in random plots (Mann-Whitney $U$-test, $U=13887, P>0.05)$. Roost trees most frequently had DBH values of $20-40 \mathrm{~cm}$.

\section{Discussion}

The M. ikonnikovi tagged in our study roosted either under bark, and/or in small cavities of a snag or a live tree (both coniferous and deciduous). Bats selected snags of an advanced (higher) stage of decay and with a larger stem as roost sites. Similar to our results, many studies indicate that snags provide important roosting 

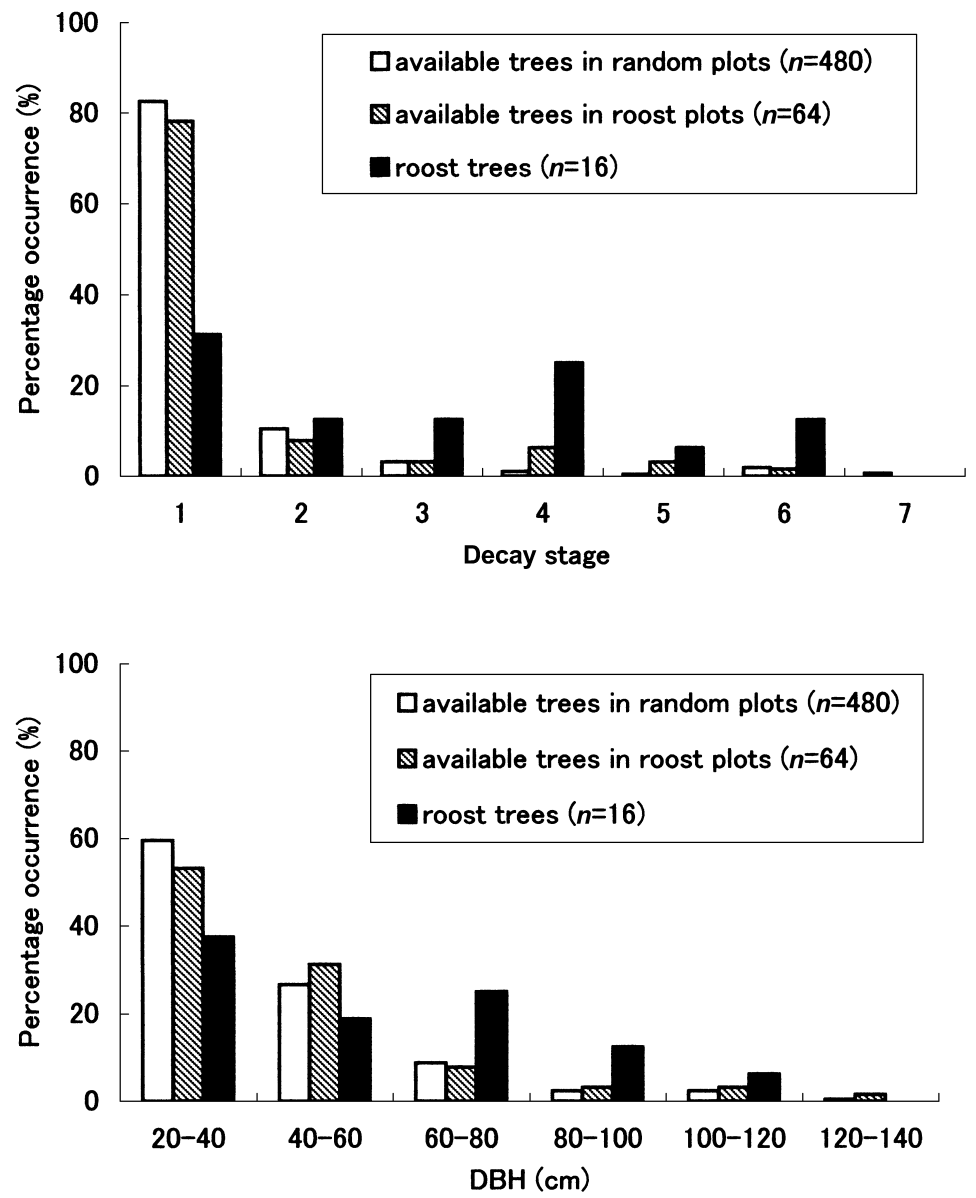

Fig. 4. Decay stages of bat roost trees compared with available trees in random plots and in roost plots.

Fig. 5. Stem diameter at breast height (DBH, cm) of bat roost trees compared with available trees in random plots and in roost plots. places for bats in temperate regions (Vonhof and Barclay 1996; Brigham et al. 1997; Foster and Kurta 1999; Sedgeley and O'Donnell 1999), although this varies among tree species and areas (Kunz and Lumsden 2003). At our study site, such snags had much exfoliating bark, and these sites were used as roost sites at the highest frequency. Temperate tree-roosting bats often select roost trees with large stem diameters (Kunz and Lumsden 2003). Sedgeley and O'Donnell (1999) reported that stem diameter was strongly correlated with the number of tree cavities. Exfoliating bark may also occur to a greater extent on trees of larger stem diameters.

In North America, crevices beneath exfoliating bark are used predominantly by Myotis spp. (Kunz and Lumsden 2003). Such space is often used by small numbers of males (M. daubentonii and M. bechsteinii) in spring (Altringham 1996), and by solitary males ( $M$. septentrionalis; Lack and Schwierjohann 2001). Space beneath exfoliating bark also functions as maternity roosts, for example, for $M$. sodalis (Humphrey et al. 1977; Kurta et al. 1996; Callahan et al. 1997), M. septentrionalis (Foster and Kurta 1999; Lack and
Schwierjohann 2001) and M. californicus (Brigham et al. 1997). In our study, one lactating female used space under bark as a roosting site with other individuals. More information about $M$. ikonnikovi roosting sites and seasonal maternal behavior is required to understand maternal roosting of this species.

The radio-tagged bats changed roosts every 1 or 2 days, and subsequent roosts tended to be close to one another in our study. It is known that many tree-roosting bats change roosts frequently, independent of their reproductive stage (Lewis 1995; Kunz and Lumsden 2003). According to Lewis (1995), bats occupying spatially abundant and less permanent roosts exhibit lower roostsite fidelity compared to other bat species utilizing less abundant and more permanent roosts. The exfoliating bark used by M. ikonnikovi may represent a spatially abundant and less permanent roost in our study area. Some species exhibit fidelity to a particular area rather than a particular tree. Vonhof and Barclay (1996) suggested that having several roost sites within a small area may minimize the energy costs of search and travel since individuals do not need to further explore unfamiliar areas. 
In this study, M. ikonnikovi changed roosts frequently, and selected snags and larger stemmed trees. This indicates that M. ikonnikovi requires many snags and large trees as roosts. According to Yasui et al. (2000), M. ikonnikovi is distributed in north-western areas of Tochigi prefecture where old growth forests remain. Old growth forests may provide a suitable habitat in terms of roosting sites. For conservation of M. ikonnikovi, a substantial number of snags and large trees must be preserved in future forest management planning.

Acknowledgments: We would like to thank Dr. Masaaki Koganezawa, Dr. Sumiko Matsumura and Dr. Masayuki Araki for advice and support. Special thanks to Hiroko Nagaoka and Hideaki Tsunenaga for assisting with radio-tracking surveys over the course of the study. We also thank Masahiko Mizuno for taking photographs in the field. We are grateful to Yoshimori Yamaguchi, Osamu Saito, Kyouji Koyanagi, Hisashi Saito, Akiko Tsuji, Takatsuna Kuroda, Yusuke Shigeta, Emiko Takayanagi, Takashi Sakaguchi, Kiyokazu Kawada, Takuya Osaki, Makito Tezuka, Hitomi Tezuka, Yuriko Yamaga, Ayako Matsuhashi, Maiko Wakabayashi, Ryoichi Tsuruma and Yasuo Matsushiro for their assistance in the field. This work was supported in part by grants-in-aid from the Ministry of Education, Science, and Culture of Japan (Grant no. 13660138), and from the Asian Bat Research Institute.

\section{References}

Abe, H., Ishii, N., Kaneko, Y., Maeda, K., Miura, S. and Yoneda, M. 1994. A Pictorial Guide to the Mammals of Japan. Tokai University Press, Tokyo, 195 pp. (in Japanese).

Altringham, J. D. 1996. Bats: Biology and Behaviour. Oxford University Press, Oxford, 262 pp.

Brigham, R. M., Vonhof, M. J., Barclay, R. M. R. and Gwilliam, J. C. 1997. Roosting behavior and roost-site preferences of forestdwelling California bats (Myotis californicus). Journal of Mammalogy 78: 1231-1239.

Callahan, E. V., Drobney, R. D. and Clawson, R. L. 1997. Selection of summer roosting sites by Indiana bats (Myotis sodalis) in Missouri. Journal of Mammalogy 78: 818-825.

Cottam, G. and Curtis, J. T. 1956. The use of distance measures in phytosociological sampling. Ecology 37: 451-460.

Foster, R. W. and Kurta, A. 1999. Roosting ecology of the northern bat (Myotis septentrionalis) and comparisons with the endangered Indiana bat (Myotis sodalis). Journal of Mammalogy 80: 659672.

Humphrey, S. R. 1975. Nursery roosts and community diversity of nearctic bats. Journal of Mammalogy 56: 321-346.

Humphrey, S. R., Richter, A. R. and Cope, J. B. 1977. Summer habitat and ecology of the endangered Indiana bat, Myotis sodalis. Journal of Mammalogy 58: 334-346.
Hunter, L. H. Jr. 1990. Wildlife, Forests, and Forestry-Principles of Managing Forests for Biological Diversity. Prentice Hall, New Jersey, $370 \mathrm{pp}$.

Japan Meteorological Agency. 2002. Mesh climatic data of Japan 2000 (1971-2000). CD-ROM. Japan Meteorological Business Support Center, Tokyo.

Kunz, T. H. 1982. Roosting ecology of bats. In (T. H. Kunz, ed.) Ecology of Bats. Pp. 1-55. Plenum Publishing Corporation, New York.

Kunz, T. H. and Lumsden, L. F. 2003. Ecology of cavity and foliage roosting bats. In (T. H. Kunz and M. B. Fenton, eds.) Bat Ecology. Pp. 3-89. University of Chicago Press, Chicago.

Kurta, A., Williams, K. J. and Mies, R. 1996. Ecological, behavioural, and thermal observations of a peripheral population of Indiana bats (Myotis sodalis). In: (R. M. R. Barclay and R. M. Brigham, eds.) Working Paper 23/1996, Bats and Forests Symposium, October 19-21, 1995, Victoria, British Columbia, Canada. Pp. 102-117. Research Branch, British Columbia Ministry of Forests, Victoria, Britich Columbia.

Lack, M. J. and Schwierjohann, J. H. 2001. Day-roost characteristics of northern bats in mixed mesophytic forest. Journal of Wildlife Management 65: 482-488.

Lewis, S. E. 1995. Roost fidelity of bats: a review. Journal of Mammalogy 76: 481-496.

Maeda, K., Kawamiti, M. and Segawa, Y. 1993. Report of the survey on hollow-tree dwelling bats in Shari-cho (II). Bulletin of the Shiretoko Museum 14: 9-15 (in Japanese).

Maeda, K. and Matsumura, S. 1997. Chiroptera. In (Mammalogical Society of Japan, ed.) Red Data of Japanese Mammals. Pp. 3155. Bun-ichi Sogo Shuppan Co. Ltd., Tokyo (in Japanese with English list).

Ministry of the Environment of Japan. 2002. Threatened Wildlife of Japan - Red Data Book, 2nd ed. - Volume 1, Mammalia. Japan Wildlife Research Center, Tokyo, 177 pp. (in Japanese with English abstract).

Mizuno, T. 1970. Note on Myotis hosonoi from Nagano. The Journal of the Mammalogical Society of Japan 5: 70 (in Japanese).

Ohwi, J. 1992. Flora of Japan, revised edition. Shibundo, Tokyo, 1716 pp. (in Japanese).

Sedgeley, J. A. and O'Donnell, C. F. J. 1999. Roost selection by the long-tailed bat, Chalinolobus tuberculatus, in temperate New Zealand rainforest and its implications for the conservation of bats in managed forests. Biological Conservation 88: 261-276.

Vonhof, M. J. and Barclay, R. M. R. 1996. Roost-site selection and roosting ecology of forest-dwelling bats in southern British Columbia. Canadian Journal of Zoology 74: 1797-1805.

Yamamoto, T., Hashimoto, H. and Ueki, Y. 1998. Bat fauna in Norikura. Gifu Prefectural Senior High School's Society for the Study of Biology Education 42: 12-18 (in Japanese).

Yasui, S., Kamijo, T., Shigeta, M. and Sato, Y. 2000. Distribution of the Ikonnikov's whiskered Bat, Myotis ikonnikovi OGNEV and its relationship to the habitat type in Tochigi Prefecture, Japan. Honyurui Kagaku [Mammalian Science] 40: 155-165 (in Japanese with English abstract).

Yasui, S., Kamijo, T., Mikasa, A., Shigeta, M., Nagaoka, H., Mizuno, M., Yamaguchi, Y., Koyanagi, K., Tsuji, A., Saito, H. and Saito, O. 2002. Summer roosts of the Ikonnikov's whiskered bat, Myotis ikonnikovi, in Nikko, Japan. Bulletin of the Asian Bat Research Institute 2: 1-7 (in Japanese with English abstract).

Yokoyama, K. 1996. Notes concerning the Fuji whiskered bat (Myotis fujiensis). Annual Speleological Research Institute of Japan, Iwaizumi 14: 17-18.

Received 29 June 2004. Accepted 11 November 2004. 
Appendix 1. Number of dead and live trees of each tree species, comparing bat roost tree with available trees in random plots and in roost plots.

\begin{tabular}{|c|c|c|c|c|c|c|}
\hline & \multicolumn{2}{|c|}{$\begin{array}{l}\text { available trees in random plots } \\
\qquad(n=480)\end{array}$} & \multicolumn{2}{|c|}{$\begin{array}{l}\text { available trees in roost plots } \\
\qquad(n=64)\end{array}$} & \multicolumn{2}{|c|}{$\begin{array}{l}\text { roost tree } \\
(n=16)\end{array}$} \\
\hline & live & dead & live & dead & live & dead \\
\hline Quercus mongolica var. grosseserrata & 159 & 6 & 7 & & 1 & 1 \\
\hline Larix leptolepis & 101 & 6 & 9 & 2 & 1 & 2 \\
\hline Ulmus davidiana var. japonica & 45 & 2 & 10 & 1 & 2 & 2 \\
\hline Acer mono & 23 & & 4 & & & \\
\hline Betula ermanii & 17 & 4 & 2 & 1 & 1 & \\
\hline Abies homolepis & 15 & 6 & 2 & 4 & & 3 \\
\hline Alnus hirsuta & 13 & 1 & & & & \\
\hline Cornus controversa & 11 & & & & & \\
\hline Sorbus alnifolia & 8 & 1 & 2 & & & \\
\hline Acer palmatum var. amoenum & 8 & & 1 & & & \\
\hline Cercidiphyllum japonicum & 6 & & 5 & & & \\
\hline Acer rufinerve & 5 & & & & & \\
\hline Alnus firmus var. nirtella & 4 & 1 & & & & \\
\hline Ostrya japonica & 3 & & & & & \\
\hline Betula maximowicziana & 3 & & 1 & & & \\
\hline Betula platyphylla var. japonica & 3 & 1 & & & & 1 \\
\hline Malus sieboldii & 3 & & & & & \\
\hline Kalopanax pictus & 3 & 2 & 1 & & & \\
\hline Fraxinus lanuginosa & 2 & & & & & \\
\hline Prunus ssiori & 2 & 1 & & & & \\
\hline Betula grossa & 2 & & & & & \\
\hline Prunus maximowiczii & 2 & & & & & \\
\hline Prunus sargentii & 1 & 1 & 1 & & & \\
\hline Betula schmidtii & 1 & & & & 1 & \\
\hline Phellodendron amurense & 1 & 1 & 1 & & & \\
\hline Acanthopanax sciadophylloides & 1 & & & & & \\
\hline Acer sieboldianum & 1 & & 1 & & & \\
\hline Stewartia pseudo-camellia & 1 & & & & & \\
\hline Fagus crenata & 1 & & 3 & & & \\
\hline Euonymus sieboldianus & 1 & & & & & \\
\hline Tsuga diversifolia & & & 1 & & & \\
\hline Carpinus cordata & & 1 & 2 & 1 & 1 & \\
\hline Acer japonicum & & & 2 & & & \\
\hline total & 446 & 34 & 55 & 9 & 7 & 9 \\
\hline
\end{tabular}

